\title{
Consultation and consensus on dose assessment during nuclear discharge authorisations: A UK example
}

\author{
K.J. Mondon, I. Fairlie', L.J. Frewer ${ }^{2}$ and C.B. Walters \\ Food Standards Agency, Aviation House, 125 Kingsway, London WC2B 6NH, U.K. \\ 115 Riversdale Road, London N5 2SU, U.K. \\ ${ }^{2}$ Diet, Health and Consumer Science Division, Institute of Food Research, \\ Norwich Research Park, Colney, Norwich NR4 7UA, U.K.
}

\begin{abstract}
In October 2000, the UK's Food Standards Agency (FSA) held a consultative exercise on the methods used to assess the potentjal consequences of proposed discharges from major nuclear plant in the UK. This paper explains why and how this meeting was heid, and discusses the effectiveness of this type of consultation for technical debates.
\end{abstract}

\section{BACKGROUND}

The Food Standards Agency's (FSA) views must be sought during the process of granting authorisations to operators of UK nuclear sites, to discharge radioactivity to the environment [1]. The FSA's primary role is to ensure the safety of the foodchain, and it has to identify the critical group which is potentially most exposed to radioactive discharges, so to judge the acceptability of exposures via food. This means that the FSA has to assess radiation doses from both food and non-food pathways.

Other organisations are also involved in similar work. The Environment Agencies, who are responsible for issuing the authorisations under the Radioactive Substances Act 1993, have recently commenced their own dose assessments [2]. Operators of nuclear plant are obliged to undertake their own risk assessment of the discharges they are proposing to make, see for example reference [3]. The UK's advisory body on radiation protection, the National Radiological Protection Board (NRPB), is also involved in dose assessments, both in terms of method development, and as a contractor to government agencies and operators [see, for example, reference 4].

FSA's methods (and previously those of $\mathrm{MAFF}^{\mathrm{l}}$ ) have been regarded by operators of nuclear plant, regulators and NRPB as too cautious, see for example, reference [5]. Consequently, FSA decided to hold a Consultative Exercise on Dose Assessments (CEDA) [6,7], which took place in October 2000.

\section{EXPECTATIONS}

The principal aim of CEDA was that it would provide an opportunity for the FSA to explain the detail and rationale of its methods to all stakeholders. It would also allow other dose assessors to comment publicly on FSA methods, and to explain their own methods. Importantly, it would provide the opportunity for all parties to debate individual points raised in presentations. It was also hoped that CEDA would achieve consensus on some issues, provide an impetus for agreed changes to be implemented, and fuel ideas for further debate, where there were unresolved issues.

\footnotetext{
' Prior to April 2000, responsibility for food safety in the UK lay with the Ministry of Agriculture, Fisheries and Food, MAFF.
} 


\section{POTENTIAL PROBLEMS}

A number of pitfalls were anticipated from the outset. These are listed below, together with the strategy adopted to minimise each one

\subsection{Avoiding bias and setting ground rules}

Participants might feel the meeting was biased towards the FSA's opinions There was also a risk that the discussion could stray from the technical aspects of a dose assessment to broader political issues concerning nuclear power. FSA took advice from the Institute of Food Research (IFR) whose Diet, Health and Consumer Science Division had considerable experience of public consultation methods $[8,9]$.

IFR advised FSA on a number of key issues: firstly, to appoint an independent chairman who was well known and respected by other stakeholders; secondly, to set up a small steering group to organise the meeting, which would be representative of the main stakeholder groups, and independent of the FSA; thirdly, to ensure early involvement of those groups who had not previously been formally engaged in discussions over dose assessments; and finally, to ensure good preparation by planning well ahead, hence giving adequate notice to participants. The Steering Group membership is shown below.

\begin{tabular}{|l|l|}
\hline CEDA Steering Group members & \\
\hline $\begin{array}{l}\text { Chaiman: Professor Bryn Bridges } \\
\text { Head of Medical Research Council Cell Mutation } \\
\text { Unit, University of Sussex }\end{array}$ & $\begin{array}{l}\text { Chaiman of UK's Committee on the Medical } \\
\text { Effects of Radiation in the Environment since 1985. }\end{array}$ \\
\hline $\begin{array}{l}\text { Mrs Jane Simmonds, Leader of Radionuclide } \\
\text { Releases Group, National Radiological Protection } \\
\text { Board }\end{array}$ & $\begin{array}{l}\text { Representing government agencies; 25 years } \\
\text { experience in radiological assessments. }\end{array}$ \\
\hline $\begin{array}{l}\text { Mr Tim Parker, Manager of Environmental } \\
\text { Monitoring and Assessments, Sellaficld, British } \\
\text { Nuclear Fuels plc }\end{array}$ & $\begin{array}{l}\text { Representing operators; } 20 \text { years experience in the } \\
\text { nuclear industry, the last 10 years in radiological } \\
\text { assessments. }\end{array}$ \\
\hline $\begin{array}{l}\text { Dr David Sumner, independent consultant on } \\
\text { radiation issues }\end{array}$ & $\begin{array}{l}\text { Representing NGOs; 20 years as a medical } \\
\text { physicist. Principal author of a book on radiation } \\
\text { nsks. }\end{array}$ \\
\hline
\end{tabular}

Planning took 12 months, and a summary timetable is shown below.

\begin{tabular}{|l|l|}
\hline Nov/Dec 1999 & $\begin{array}{l}\text { Appointment of 2-man FSA team to organise conference; draft invitee list } \\
\text { drawn up; meeting with extemal advisors on consultative process; } \\
\text { appointment of steering group chairman }\end{array}$ \\
\hline Jan 2000 & $\begin{array}{l}\text { Meeting with NGOs to explain purpose of meeting and set ground niles; } \\
\text { appointment of steering group members; date decided and venue booked; } \\
\text { draft budget drawn up }\end{array}$ \\
\hline Mar 2000 & $\begin{array}{l}\text { First meeting of Steering Group, to discuss practical arrangements, ground } \\
\text { rules, issues to be addressed, format of meeting, and invitee list, } \\
\text { announcement of meeting to public groups living close to all nuclear sites in } \\
\text { the UK }\end{array}$ \\
\hline May 2000 & Invitations issued \\
\hline September 2000 & Second meeting of steering group to discuss final arrangements; CEDA \\
\hline
\end{tabular}

${ }^{2}$ The meetings were organised by FSA and also attended by Lynn Frewer from the Institute of Food Research, who provided advice on the consultation process. 


\begin{tabular}{|c|c|}
\hline & written papers completed, agenda and meeting papers sent to participants \\
\hline October 2000 & CĒDA meeting held \\
\hline December 2000 & $\begin{array}{l}\text { Draft of meeting report circulated to steering group for comment, IFR } \\
\text { evaluation report published }\end{array}$ \\
\hline January 2001 & $\begin{array}{l}\text { Meeting of steering group to discuss draft report; } 2^{\text {sT }} \text { draft circulated to all } \\
\text { participants }\end{array}$ \\
\hline May 2001 & Publication of CEDA report \\
\hline
\end{tabular}

\subsection{Ensuring adequate representation}

The main challenge was to secure the participation of the widest possible selection of people who had a genuine interest in assessments, professional or otherwise, so as to ensure profitable debate. FSA staff first drew up a draft list of likely organisations and the individuals who could represent them. The Steering Group was asked to comment on those sectors that represented their interests. This ensured all appropriate groups were included, and the most suitable person was selected from each group. The main participant groups were operators of nuclear plant, regulators and associated agencies, non-governmental organisations (NGOs), those who might be exposed to the discharges ie the public, and independent experts on radioactivity in the environment. Fifty people finally attended.

\subsection{Ensuring all participants were aware of current methods}

Pre-meeting briefing was essential, firstly to bring everyone up to date on methods, and secondly, to cater for different levels of technical knowledge. Five papers were written. FSA documents were: an introductory paper covering the basic aspects of a dose assessment; a paper specifically on the FSA method, illustrated by case studies; a subsidiary paper which contained related issues on dose assessments, but which would not be covered during CEDA (for example, uncertainty and variability in assessments, and collective dose). These papers were written first, and the members of the Steering Group then used them to prepare their own position papers. All these written papers were circulated to participants one month before the meeting, to allow time for reading and reflection. In addition, an early meeting was held with representatives of some nongovernmental organisations to explain the technical background to some of the issues.

At the start of the meeting, presentations from the FSA and each member of the Steering Group were given to illustrate each party's main principles and again, to bring everyone up to speed on the day.

\subsection{How to conduct and adequately report the meeting}

It was decided by the Steering Group that discussion had to be highly targetted to ensure good use of time, and to prevent the debate from becoming too general. Discussion points covering the main aspects of a dose assessment, based on the critical group concept, were drawn up, and are summarised in section 5 . To assist the debate, the views of Steering Group members on each point were summarised in tables given to participants in advance. 
The Steering Group also decided that comments would be attributed and that participants would be informed of this prior to the meeting, and reminded on the first day of debate. The meeting was taped, and notes made. From these notes and tapes, a near verbatim account of the debate was prepared from which summaries of the discussion were drawn together. The discussion section of an early draft of the report was sent to all participants to ensure they were content with what had been attributed to them.

\subsection{Polarity of views that would not be amenable to resolution.}

It was anticipated that on some issues, it was unlikely that agreement could be reached between the different groups. Nonetheless, it was useful for the participants to identify these differences of position as they could provide the context for understanding other parts of the discussion. Examples of some of these issues are given in section 5 .

\section{PHYSICAL ARRANGEMENTS}

The meeting was held over 2 days, on a university campus with most people staying on site. This arrangement gave people the opportunity to talk to one another, both during the formal debates, and more informally, outside of the meeting. The placing of participants,both during the meeting and during the formal dinner, was arranged to encourage debate between different stakeholders. FSA paid for food, accommodation and travel where these costs could not be met by participants' organisations.

\section{THE DEBATE}

The main discussion points were:

- What assumptions should be made about the habitation of the critical group

- What sources, types and consumption rates of local foods should be assumed

- What habits additional to food consumption should be included

- How should the different exposure routes be combined to produce total exposure

- How should pre-existing anthropogenic sources be taken into account

- The desitability of having altemative methods of assessment used by different organisations

- Presentation of results of an assessment to the public

Discussion on where the critical group was assumed to live, and habits associated with aquatic pathways was generally uncontroversial, all parties agreeing that existing methods were adequate. The assessment of total risk was a much repeated issue during the debate, most parties thinking that the assessment of dose from a proposed discharge had to be considered along with other potential exposures from anthropogenic sources, and in particular historic discharges and direct shine from sites. Regulators however, held the opinion that the site or source constraint alone should be the yardstick used for judging the acceptability of future discharges.

Differences in opinion remained on the questions of which foods were assumed to be local to a nuclear site, and how much of these foods were consumed by the critical 
group. Specifically, the FSA has been left to consider what it should do with distributions of doses based on habits taken from surveys. Non govemmental organisations in particular thought the highest point on the distribution should be used, on the basis that it represented a habit which had been observed during surveys. Operators and regulators thought that a mean value was more appropriate, because of ICRP recommendations about the use of a critical group, and that other assumptions associated with the distribution were cautious.

Some issues were debated at length even though they were not on the agenda. In particular, there was the issue of what the public dose limit actually meant. In the UK, a limit of $1 \mathrm{mSv}$ per year to all individuals from controllable sources is enshrined in legislation [10], but guidance to this legislation [11] refers to the mean of the critical group as being the appropriate statistic for comparison with the mean. It was also pointed out that proving that the public limit had been exceeded would be almost impossible in a court of law.

There was unanimous agreement that all involved in assessments had to work more closely together, share ideas and data and ensure that what they did was justified and transparent.

\section{EVALUATION OF CEDA}

IFR evaluated CEDA by asking participants to score it on a number of evaluation criteria. [12]. The meeting scored very highly on "independence" (it was conducted independently), "transparency" (it was conducted in an open and fair manner), "resources" (respondents felt they had been provided with all the resources they needed to contribute effectively) and "cost effectiveness" (respondents believed the exercise was cost effective and unlikely to be bettered in this respect by another procedure). The exercise scored fairly highly on the criteria of "influence" (respondents believed the results would genuinely influence FSA thinking), "task definition" (the exercise was well defined) and "structured decision making" (the exercise was structured in a way that logical and consistent outcomes would emerge from the process). There was disagreement among participants over the extent to which they perceived CEDA had met the criterion of "representativeness" (ie was there adequate representation of all the affected stakeholders). In follow up telephone interviews conducted by IFR after the exercise, most participants said they had attended the meeting to learn more about the differences in dose response methodologies. Some said they had hoped to influence the debate in some way and a smaller number had hoped the meeting would result in closer agreement between the different stakeholders regarding methodology in dose assessments.

\section{CONCLUSION}

Although CEDA took considerable time and resources to organise, it has proved a very useful foram. Participants appreciated the FSA's attempts to promote dialogue between those with different views, and thought that this had been done in a fair and independent way. In particular, the chairman was highly praised. The only concem amongst some participants was that certain groups were under-represented. All participants said they 
would attend a similar exercise in the future. In terms of conclusions from the meeting, there was a clear message for Government departments and agencies to work more closely together and work has started to take this matter forward. Importantly for the FSA, the NGO presence at the meeting has given a clear endorsement over its generally cautious approach to public dose assessments.

The meeting far exceeded the expectations of both the FSA and the Steering Group in achieving its goals. If CEDA is used as a model for other technical debates, key aspects to take into account are to allow sufficient planning time and resources, to recruit an independent chairman and small steering group, to ensure good stakeholder representation, and to plan a highly targetted debate. Finally, for participants to feel such meetings are of use in the longer term, host organisations must be willing to make policy changes in line with any consensus reached during the debates.

\section{References}

[1] UK Parliament. Environment Act 1995. HMSO, London, UK 394pp

[2] Environment Agency, Scottish Environment Protection Agency, Department of the Environment in Northem Ireland and the National Radiological Protection Board. "Discharges of Radioactive Waste to the Envionment: Principles for the Assessment of Public Doses (Consultation Document)" 2000

[3] BNFL "Supporting documents 6/7: Radiological impact assessment for discharges of aerial and liquid effluents" in "Radioactive Substances 1993: A package of information in support of the Environment Agency's review of technitium-99 discharges from BNF plc Sellafield into the Irish Sea" October 2000. Environment Agency, UK.

[4] Smith KR, Brown J, Jones JA, Mansfield P, Smith JG and Haywood SM. Uncertainties in the assessment of terrestrial foodchain doses (NRPB-M922, NRPB, Chilton, Didcot, UK, NRPB, 1998) 90pp

[5] Radioactive Waste Management Advisory Committee. "Advice on issues which need to be addressed in the guidance to be given to the Environment Agencies on the principles for determining radioactive waste discharge authorisations" (Department of the Environment, Transport and the Regions, London, UK, 1998) 38pp

[6] Food Standards Agency "Consultative Exercise on Dose Assessments $-3^{\text {rd }} / 4^{\text {th }}$ October 2000" (FSA, London, UK, 2001) 135pp

[7 Bridges BA, Parker T, Simmonds JR and Sumner DJ Radiol Prot 21 (2001) 125-132

[8] Rowe G and Frewer LJ (2000) Sci, Technol and Human Values 25 3-29

[9] Rowe G, Marsh R and Frewer LJ. Evaluation of a

Deliberative Conference using Validated Criteria. Submitted to Sci, Technol and

Human Values.

[10] lonising Radiations Regulations 1999, SI 1999/3232 Stationery Office, UK 1999

[11] HSE 2000, Approved Code of Practice and Guidance to Ionising Radiations Regulations 1999. HSE Books, Suffolk, UK.

[12] Rowe G, Marsh R and Frewer L. Food Standards Agency Consultation Exercise on Dose Assessment: An evaluation (Institute of Food Research, Norwich, UK, 2000) 25pp 